\title{
First Record of the Genus Hemigaster (Hymenoptera: Ichneumonidae: Cryptinae) from Korea
}

\author{
Seung-Ho Oh and Jong-Wook Lee* \\ Department of Biology, Yeungnam University, Gyeongsan 712-749, Korea
}

\begin{abstract}
We report the species Hemigaster taiwanus for the first time in Korea. This genus is also new to Korea. A diagnosis and photographs of diagnostic characters of the species are provided.
\end{abstract}

Key words: Hemigaster taiwanus, Cryptinae, Ichneumonidae, Hymenoptera, Korea

\section{INTRODUCTION}

The Cryptinae is the most diverse subfamily among the ichneumonids subfamilies. It is recognized about 4,700 described species and 395 genera in the world. A total 35 genera and 59 species have been reported from Korea (Yu et al., 2005). The genus Hemigaster Brullé, 1846 is a moderate sized group belonging to the subfamily, and comprises twelve species from Australian, eastern Palaearctic and Oriental regions (Yu et al., 2005). All species, except for H. luteus Brullé that was recorded from Australia, are distributed in the Oriental region (Townes, 1970). However, one species H. taiwanus (Sonan, 1932), originally described as one of Oriental element from Taiwan, was also recorded in eastern Palearctic region (Henan province, China) by Sheng et al. (2000).

The genus Hemigaster is easily recognized by the combinations of following characters; frons with a median compressed horn, second and third tergites enlarged, more or less fused together, and other tergites mostly retracted under third tergite.

Biology of this genus is poorly studied, but Townes (1970) reported that host of this genus may be the family Limacodidae (Lepidoptera).

In this paper, we report the species $H$. taiwanus for the first time in Korea. The genus is also newly recorded in Korea. We provide a diagnosis and photographs for diagnostic characters of the species.

\section{MATERIALS AND METHODS}

All the materials used in this study have been assembled by

\footnotetext{
*To whom correspondence should be addressed

Tel: 82-53-810-2376, Fax: 82-53-811-2376

E-mail: jwlee1@yumail.ac.kr
}

the authors and other fellow workers or loaned from foreign collections. Examined specimens are deposited in Department of Biology, Yeungnam University, Gyeongsan, Korea (YNUE). Voucher specimens were loaned from Deutsches Entomologisches Institut, Leibniz-Centre for Agricultural Landscape Research, Germany (DEI). The morphological terminology used in this study follow those of Townes (1970), Yu et al. (2005) and Jonathan (2006). Photographs of specimens are captured with Axiocam MRc5 camera through a stereomicroscope (Stemi SV 11 Apo; Carl Zeiss, Göttingen, Germany), and produced with AxioVision40AC software (Carl Zeiss, Göttingen, Germany).

Abbreviations for type information are as follows: TS, Type species; TL, Type Locality; TD, Type Depository. For institutions: TARI, Taiwan Agricultural Research Institute, Entomology Collection, Wufeng, Taiwan.

\section{TAXONOMIC ACCOUNTS}

Order Hymenoptera

Family Ichneumonidae Latreille, 1802

Subfamily Cryptinae Kirby, 1837

Tribe Hemigasterini Ashmead, 1900

Genus ${ }^{1 * H e m i g a s t e r ~ B r u l l e ́, ~} 1846$

Hemigaster Brullé, 1846: 266. TS: Hemigaster fasciatus Brullé, 1846. Designated by Viereck, 1914.

Chreusa Cameron, 1899: 209. Synonymized by Cushman, 1937. TS: Chreusa fulvipes Cameron, 1899. Designated by Ashmead, 1900.

Asius Tosquinet, 1903: 260. Synonymized by Townes et al., 1961. TS: Asius fulvus Tosquinet, 1903.

Charmis Tosquinet, 1903: 274. Synonymized by Townes et al., 1961. TS: Charmis limbatus Tosquinet, 1903=Hemigaster fulvipes (Cameron, 1899).

1 *세마디뾰족맵시벌속(신칭) 


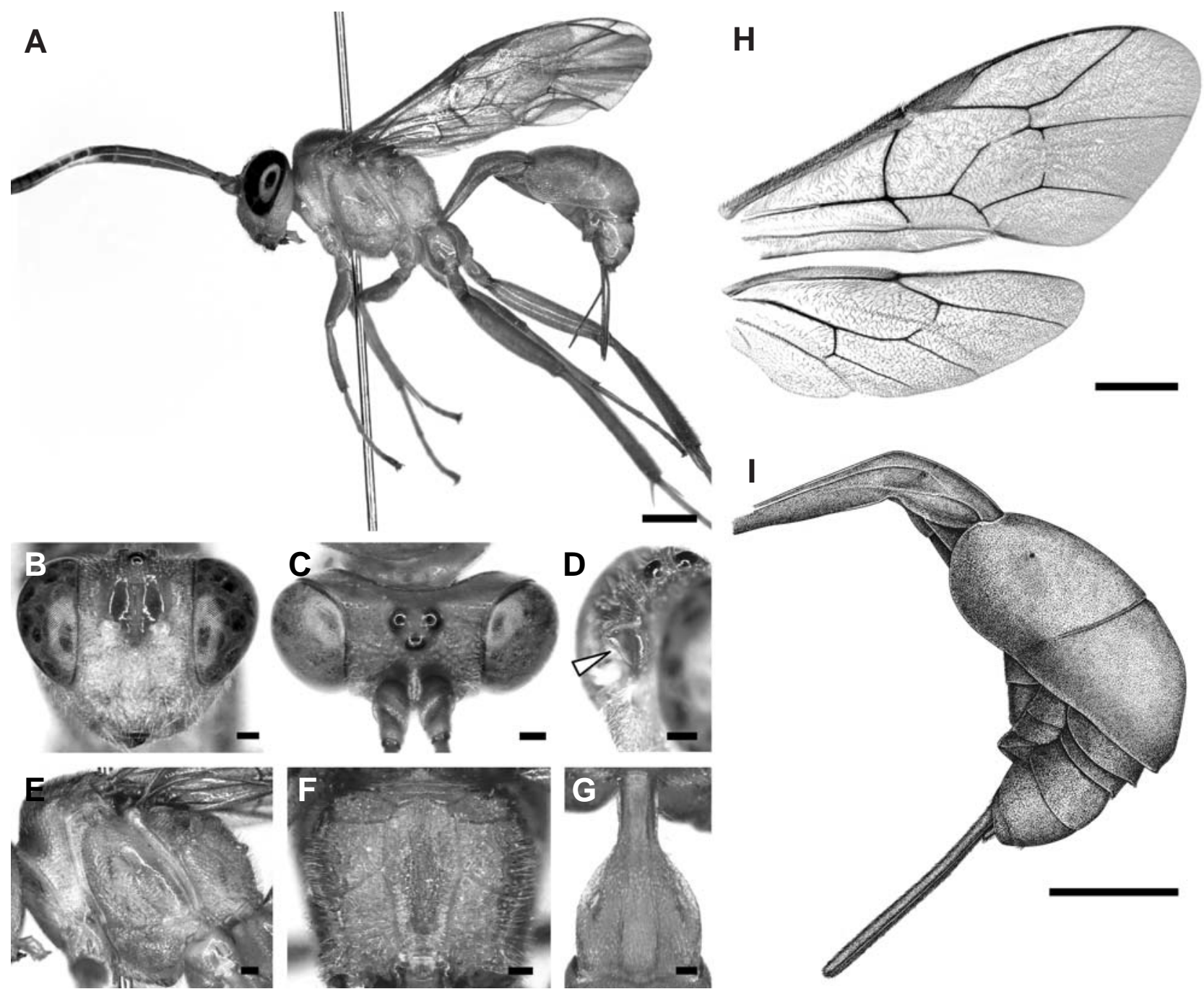

Fig. 1. Hemigaster taiwanus, female. A, Body, lateral view; $B$, Head, frontal view; C, Head, Dorsal view; $D$, frontal horn; $E$, Thorax, lateral view; F, Propodeum; G, First tergite; H, Wing; I, Abdomen. Scale bars=1 mm (A, H, I), $0.2 \mathrm{~mm}(B-G)$.

Cryptodema Morley, 1913: 312. Synonymized by Cushman, 1937. TS: Cryptodema anormis Morley, 1913=Hemigaster fulvipes (Cameron, 1899).

Diagnosis. Antenna lanceolate in female, without tyloids and not lanceolate in male. Frons with a median compressed horn. Clypeus weakly convex, with or without a median tooth. Mandible short, its basal tooth a little longer than apical tooth. Sternaulus extending to mesocoxa. Fore wing without areolet. Second and third tergites enlarged, more or less fused together, the other tergites retracted under third tergite.

\footnotetext{
$1 *$ Hemigaster taiwanus (Sonan, 1932) (Fig. 1A-I)

Chreusa taiwana Sonan, 1932: 85 Type: Female, TL: Tai-
}

wan, TD: TARI.

Hemigaster taiwana: Townes et al., 1961: 133.

Diagnosis. Female: Body reddish brown, with reddish or yellowish hairs (Fig. 1A). Apical half of 4th to basal half of 9th flagellar segments white. The other flagellar segments, hind tibia apically and ovipositor sheath dark brown. Mandibular teeth black. Head with coarse punctures. Antenna with 24-27 flagellar segments, lanceolate; 9th to penultimate flagellar segments widened and ventrally flattened. Frons with a median compressed horn (Fig. 1C, D); median horn bilobed at apex, and median part of horn diaphanous (Fig. 1D). Face with a median vertical ridge. Clypeus not separated from face by groove (Fig. 1B), moderately convex, and

$1 *$ 대만세마디뾰족맵시벌 (신칭) 
apical margin without a median apical tooth. Pronotum with coarse punctures, and lower part transversely striated. Notauli narrow and shallow, but distinct. Scutellum large, with hairs longer than ones of mesoscutum, and lateral carina distinct. Mesopleurum coarsely punctate, sometimes median part striated, with epicnemial carina close to anterior margin of mesopleurum. Propodeum (Fig. 1F) rugose, except for punctate superomedia area; longitudinal carina and anterior transverse carina complete, posterior transverse carina interrupted in the area superomedia; propodeal spiracle elongated. Forewing without second intercubitus (Fig. 1H). Hind wing with five distal hamuli. First tergite with a pair of dorsomedian carinae extending to apex and dorso-lateral carina reaching to spiracle (Fig. 1G). Lower part of second and third tergites fused in lateral view (Fig. 1I). Third tergite strongly rounded at apex. Remainder of abdomen retracted under third tergite.

Male: Male similar to the female, but differ in the following characters: flagellar segments without white band, not lanceolate, and antenna with 23 to 24 flagellar segments.

Material examined. KOREA: GW, Donhae-si, Samhwa-dong, Mureung valley (N37 27'52" E129 01'26"), 4-15 Jul. 2005

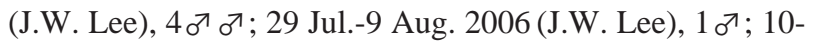
21 Jul. 2007 (J.W. Lee), 1 우; 21 Jul.-5 Aug. 2007 (J.W. Lee),

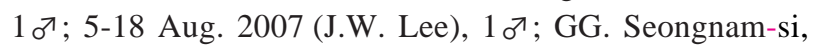
Changgok-dong, 21 Aug. 1992 (S.M. Choi), 1 우; CB, Danyang-gun, Cheondong-ri, Sobaeksan, Bukbusamuso, 7 Jul.2 Aug. 2005 (J.W. Lee), 3 ठ ठ Worak-ri, Woraksan, Deoksanmaepyoso, 29 Jun.-17 Aug. 2006 (J.W. Lee), 1 o $^{\text {T }}$; Daejeon-si, Seo-gu, Wolpyeong-dong, Wolpyeong park, 20 Jun.-10 Aug. 2007 (J.W. Lee), 8 우 우, 4 ๙ $^{\nearrow}$; JN, Jeongeup-si, Naejang-dong, Naejangsan, Ansam, 25 Aug. 2004 (K.B. Kim), 1 ð; 25 Aug. 2004 (J.W. Lee), 1 ণ ${ }^{7}$ : Ibam-myeon, Deungcheon-ri, Naejangsan, 26 Aug. 2004 (M.K. Yun), 1 우; Jangseong-gun, Bukha-myeon, Naejang-

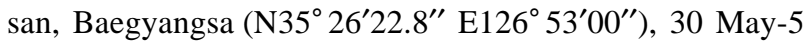
Aug. 2008 (J.W. Lee), 1 우; 5-25 Aug. 2008 (J.W. Lee), 1 万ొ. TAIWAN: Taihorin, 7 Nov. 1911 (H. Sauter), 1 우; Kankau, Koshun, 22 Apr. 1912 (H. Sauter), 1 우; Jun. 1912 (H. Sauter), $1 \sigma^{7}$.

Distribution. Korea (new record), China, Taiwan.

Host records. Unknown.

\section{ACKNOWLEDGEMENTS}

We thank Dr. A. Taeger of DEI for providing voucher specimens. We also thank Dr. Kyong-In Suh for useful comments on this paper. This study was supported by the Korean Institute of Environmental Science and Technology, Ministry of Environment grant (KIEST 052-082-072).

\section{REFERENCES}

Ashmead, W.H., 1900. Classification of the Ichneumon flies, or the superfamily Ichneumonoidea. Proc. U. S. Natl. Mus., 23(1206): 1-220.

Brullé, M.A., 1846. Tome Quatrième. Des Hyménoptères. Les Ichneumonides. In Lepeletier de Saint-Fargeau A. "Histoire Naturelles des Insectes. Paris”, pp. 56-324.

Cameron, P., 1899. Hymenoptera Orientalia, or contributions to a knowledge of the Hymenoptera of the Oriental Zoological Region. Part VIII. The Hymenoptera of the Khasia Hills. First paper. Mem. Lit. Philos. Soc. Manchester, 43(3): 1-220.

Cushman, R.A., 1937. H.Sauter's Formosa-collection: Ichneumonidae. Arb. morph. taxon. Ent., 4: 283-311.

Jonathan, J.K., 2006. Ichneumonologia Indica, Part-1, Hymenoptera: Ichneumonidae, Zool. Surv. India., Kolkata, pp. 1-680.

Latreille, P.A., 1802. Histoire naturelle, générale et particulière des crustacés et Insectes. Tome troisieme, Paris, pp. 1-468.

Morley, C., 1913. The fauna of British India including Ceylon and Burma, Hymenoptera, Vol. 3. Ichneumonidae. British Museum, London, pp. 1-531.

Kirby, W., J. Richardson and W. Swainson, 1837. Fauna Boreali-Americana. Part the Fourth and last. [Richardson, Swainson \& Kirby-Faun. Bor. Amer. part 4] J. Fletcher. Norwich. 325pp. p. 260, 261.Cryptocentrum [Cornell (Comstock) microfiche E-11 no.537].

Sheng, M.L., S.P. Sun, H.C. Pei, Z.H. Shang, F.Y. Shen and W.Z. Huang, 2000. [Hymenoptera: Ichneumonidae.] (in Chinese with English summary). In Shen, X.C. and H.C. Pei, 'The Fauna and Taxonomy of Insects in Henan. Vol. 4. Insects of the Mountains Funiu and Dabie Regions'. China Agricultural Scientech Press, Beijing, pp. 373-379.

Sonan, J., 1932. Notes on some Braconidae and Ichneumonidae from Formosa, with descriptions of 18 new species. Trans. Nat. Hist. Soc. Formosa. Taihoku, 22: 66-87.

Tosquinet, J., 1903. Ichneumonides nouveaux. (Travail posthume). Mém. Soc. Ent. Belg., 10: 1-403.

Townes, H.K., 1970. The genera of Ichneumonidae. Part 2. Mem. Amer. Entomol. Ins., 12: 1-537.

Townes, H.K., M. Townes and V.K. Gupta, 1961. A catalogue and reclassification of the Indo-Australian Ichneumonidae. Mem. Amer. Entomol. Ins., No. 1. pp. 1-522.

Viereck, H.L., 1914. Type species of the genera of Ichneumon flies. U. S. Nat. Mus. Bull., 83: 1-186.

Yu, D.S., K. van Achterberg and K. Horstmann, 2005. Biological and taxonomical information: Ichneumonoidea 2004. Taxapad Interactive Catalogue, Vancouver.

Received October 22, 2008 Accepted November 7, 2008 